\title{
PREDICTION OF THE DEVELOPMENT OF GROUNDWATER QUALITY IN A FINISHED SLUDGE LAGOON
}

\author{
PETR ČERNOCH ${ }^{a, *}$, JiŘí KOŠŤÁL ${ }^{b}$ \\ a ČEZ Energetické produkty, s. r. o., Komenského 534, 25301 Hostivice, Czech Republic \\ ${ }^{b}$ INSET, s. r. o., Divize Energetika, Lucemburská 7, 13000 Praha 3, Czech Republic \\ * corresponding author: cernoch.petr@inset.com
}

\begin{abstract}
This study deals with prediction of the development of groundwater quality in a finished sludge lagoon. For depositing and predicting secondary float energy by-products, it is appropriate to use mathematical modelling. The implementation of relevant input data from long-term monitoring is suitable as an application for verification as well. The main output was the determination of the necessary priorities and geotechnical risks in solving the final state of the area of interest, especially regarding solving of the drainage system in the subsequently finished sludge lagoon.
\end{abstract}

KEYWORDS: Transport of contaminants, sludge bed, geotechnical risks.

\section{INTRODUCTION}

When depositing secondary energy by-products from coal-fired power plants, several crucial questions arise in relation to the ambient environment and potential geotechnical risks.

Regarding the remediation and revitalisation of former sludge beds by way of depositing secondary energy by-product, it is necessary to point out fundamental phenomena related to the impact of the structure of interest on the ambient environment and potential geotechnical risks. This concerns mainly a rise in groundwater level due to superimposed load on the structure [1]. When the secondary energy by-products are deposited, this new layer can sag and consequently, open tensile fractures may appear in it. Therefore, it is advisable to pay close attention to the analysis of changes that can arise when former sludge beds are covered with a remediation layer. In particular, there is a risk of restoring the problem as the groundwater outflow conditions may change, which can lead to the transport of potential contaminants from the former sludge beds to the ambient environment. At the same time, the stability of some parts of the structure may be affected locally and the overall stability in a wider area may also be affected, especially if the uplift pressure at the base of the structure increases [2].

The above-mentioned risks may be disclosed in time and subsequently eliminated thanks to the implementation of hydrogeological model calculations which focus on the simulation of changes in outflow conditions caused by depositing secondary energy by-products. Typical tasks mainly include monitoring the impact of hydro-regime changes on the stability of a former sludge bed (or rather the finished sludge lagoon), verification of possible spreading of potential contaminants in the saturated ground environment, and groundwater level development in various alternative solutions for overall capacity extension and reclamation of the structure [3, 4.

The prediction of groundwater quality development (modelling of contaminant transport) was implemented in the area of two (former) sludge beds. The first sludge bed was created in a depressed terrain by enclosing it with a starter dam. It was hydraulically operated between 1967 and 1990. The neighbouring sludge bed was located in the area of a former quarry in which mining was discontinued in 1983. Ash deposition by way of sluicing in the central part of the structure of interest, started in 1990 and has continued to this day while the sluicing is scheduled to stop at the end of 2017 or the beginning of 2018. A hydromixture (a mixture of slag and water) is sluiced to the sludge bed. Simultaneously, the implementation since 1997 of coal-fired power plant desulphurisation using the wet lime scrubbing process, a pre-reclamation arrangement for landscape recovery has been modelled on the surface of a sludge bed ash beach using a stabilised mixture prepared from secondary energy by-products (a mixture of fly ash, lime, wastewater, etc.).

\section{INPUT DATA}

First, a geological model was created and hydrodynamic (hydraulic) properties assigned to partial geological units. After that, boundary conditions were defined and then a computing grid was established. For the partial tasks to be solved, it was essential to first solve the hydrogeological model with steady groundwater flow in a wider area of interest. Thus, the precondition of setting actual initial and boundary conditions at the border of the model area is met.

Visual ModFlow Flex 2015.1. was used for the modelling, including the implemented modules: MODFLOW 2005 U.S. Geological Survey to find out the course of the groundwater flow in the saturated ground 
environment, MT3MDS for the transport of contaminants and ZONEBUDGET to establish the groundwater amount in pre-defined 3D bodies (areas). Afterwards, VMOD 3D-Explorer enabled us to display both inputs and outputs of individual models in $3 \mathrm{D}$ form.

\subsection{MOdEL GeOMETRY AND BOUNDARY CONDITIONS}

The locality of interest was modelled over a total surface area of approx. $3.2 \times 2.8 \mathrm{~km}$ (i.e., an area of approx. 905 hectares was simulated). The lower limit of the model was selected in such a way that the total vertical profile adequately covered all the geological units concerned and their general course. Great emphasis was laid on creating geological boundaries of tuffitic rocks (forming an impermeable barrier between the two sludge beds) and coal, including coalbearing clays (especially the course of the coal seam and its non-balanced residues). The geological model was identical for all partial numerical models, only the input of the terrain surface course differing in the variants. The current terrain, the filled body after slag sluicing was discontinued (12/2017) and after that depositing of stabilised mixture is finished, that is before the reclamation starts in 2025 .

When the geological model was implemented (Figure 1), the conceptual model was solved, and later there followed the numerical model. The conceptualisation consisted in the schematisation of all aspects of the area of interest, i.e., the geometry of the analysed area and the groundwater flow conditions. Moreover, the model material composition was simplified while respecting all the defined boundary conditions.

A specific constant groundwater level was used as the first-type boundary condition for the modelled borders of the area of interest. The level was not entered as constant up to the border but as respecting the found data (groundwater level) from the hydrogeological model of the wider surroundings of the area of interest. In addition, a second-type boundary condition was introduced, namely Recharge. To avoid separate entry of another boundary condition Evapotranspiration (difficult determination of amount and depth range), was already included when the Recharge boundary condition was entered - and this value was reduced. Superficial saturation and local watercourses were included in the model as a $3^{\text {rd }}$-type boundary condition - River. Another $3^{\text {rd }}$-type boundary condition was the course of levels in the stream tubing (Drain) and drainage system for the sludge bed seepage water. The boundary condition of the Lake included the artificially maintained constant height of the free water level in the residual sludge bed lake and hydro-mixture sluicing. Water recharge from the sluiced hydro-mixture can be derived from the known value of the hydro-mixture flow rate through the sluice pipeline minus the slag content. The entered $4^{t h}$-type boundary condition, Pumping Wells, represented the effect of overflow towers. The initial condition (Initial
Head) with the starting groundwater level calculated within the steady groundwater flow modelling in the wider area of interest, was used in the entire simulated model area.

\subsection{MATERIAL CHARACTERISTICS}

The following basic geological units were selected for the solved models: stabilised mixture; slag-ash sediment; stockpiled soil; Holocene deposits including deluvial-fluvial soils; aeolian or aeolian-deluvial sediments of loess or of loess-soil nature; fluvial Pleistocene gravel accumulations - terraces; overlying part of Most formation - clays with sand fraction; coal series (seam and non-balanced residues) - coal; coal claystone; pyroclastic rock including the underlying part of Most formation - tuffs and tuffits of volcanic series; varied claystones and tuffitic clays of underlying series; Cretaceous rock of Turonian age - marlites and lime claystones; vulcanites (Neogene effusive magmatites) olivine basalts, nephelinites and leucites. The selection of all 11 various geological environments made for a certain simplification consisting in the unification of soils and rocks into so-called quasi-homogeneous units (i.e., units with similar geological and hydrogeological properties), although they may be heterogeneous as to their lithology and genesis.

Hydrodynamic parameters for each geological unit were obtained from hydrodynamic tests, well logging, laboratory analyses, and also partially derived from archive searches in Czech and foreign professional literature [5]. The determination of the ash hydraulic parameters is very difficult. From experience in other similar fields, it is known that filtration coefficients in a saturated ash body in analogous conditions, as verified by a pumping experiment, showed differences of one or two orders of magnitude. Differences between filtration coefficients in the horizontal and vertical directions may even be a hundredfold. Moreover, in the central part of the sludge bed (near the overflow towers) the finest-grain ash fraction tends to settle and, mainly thanks to the existence of a free water surface in this area, the difference between the vertical and horizontal permeability values is almost entirely blurred. For those reasons, flatly introduced filtration coefficient values were adequately adjusted within the modelling. At the same time, crevice permeability was not considered in the solved model calculations. It plays a part in underlying Cretaceous rocks and the stabilised mixture body. Considering the position of the Cretaceous deposits (deeper groundwater circulation), only a negligible error results in the calculation. It is true for both the slag-ash sediment and stabilised mixture that in reality (on the macro-scale), their permeability will be greater than the laboratory value. However, this is insignificant in the presented calculations.

Within the solution, the reference groundwater levels obtained from long-term monitoring of the area of interest were entered. Additionally, earlier chemical 


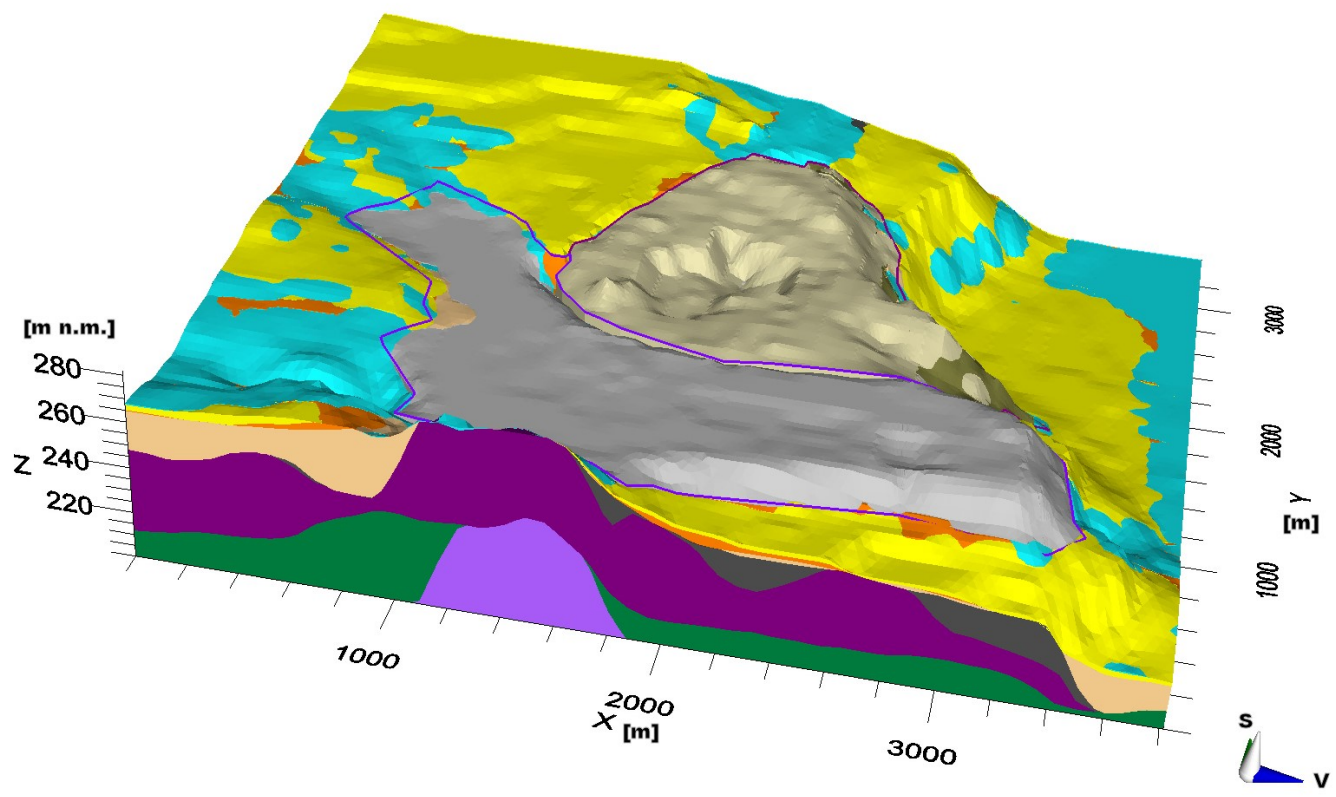

FiguRE 1. Initial geological model (superelevated 10 fold).

analyses were searched out, groundwater samples were taken, and their subsequent laboratory analyses undertaken. The input values entered in the calculation model were average values obtained from the reference period from 2009 to 2016. The groundwater level values measured in the monitoring hydro-wells served for the calibration and backward verification of the model. The latter compared whether the calculated course of the groundwater level in the model initial time corresponded to the actually found levels to the maximum extent, i.e., the long-term average in recent years.

\section{Calculation, Calibration And BACKWARD VERIFICATION}

When solving the transport of contaminants in the area of interest, it was necessary to implement partial groundwater flow models. In general, four basic models were solved:

- Model 1: groundwater amount and quality in the area of the sludge beds in simultaneous slag sluicing to the other sludge bed;

- Model 2: prediction model of groundwater quality after the sluicing is discontinued for selected chemical indicators (until 2025);

- Model 3: prediction model of the groundwater amount flowing out of the area of both sludge beds from the discontinuation of slag sluicing to the other sludge bed till the discontinuation of depositing secondary energy by-product - final shape before reclamation (until 2025);

- Model 4: prediction model of the groundwater level when the water regime has stabilised after the discontinuation of sluicing.
Except for the first and partly also the last model, with the steady state of groundwater, a so-called "steady-state simulation", the variants were always time-varying. The groundwater course reacting to time changes was solved, as a response to the change in the entered boundary conditions. In the case of Model 1, we used the standard computing module of PCG2 (preconditioned conjugate-gradient method) to numerically solve the simulated equations of the linear groundwater flow model using modified incomplete Cholesky and polynomial predictions. For the other models, the computing method of GMG (Geometric Multigrid Solver) served the purpose of solving the corresponding matrices. This method is based on the conjugate gradient algorithm like the previous PCG2, but unlike PCG2 it was developed especially for solving groundwater flow models with a numerical grid of finite differences. For models 1 and 2 (after timevariant groundwater flow iterations were successfully finished) the advective flow method of UFD (upstream finite difference) with the implicit computing module of GCG (Generalized Conjugate Gradient solver) was used to calculate the transport of contaminants. Once the obtained results had been reviewed, we proceeded to the calibration and backward verification of the numerical model.

Hydrogeological model calibration consisted in a gradual change in the input parameters until an acceptable agreement between the measured and calculated values was achieved. In the first step, the achieved groundwater levels in zero time were compared with the measured data in each model variant. Then the concentration values for the monitored chemical indicators were calibrated as well.

Numerical model verification was made possible mainly thanks to a sufficient amount of data obtained 
from the long-term monitoring of the area of interest performed for many years by INSET s.r.o.

In summary, we can conclude that, despite its extreme complexity (extensive territory, complicated geological structure, large number of boundary conditions, etc.), the implemented model of the solved area achieved, in all its partial variants, a very good agreement with the documented values from the hydrogeological and hydrochemical monitoring.

\section{Results of model CAlCUlations}

All model variants included the effect of the sludge bed drainage system. In the implemented mathematical modelling, the effect of the upper near-surface aquifer was connected with deeper groundwater circulation. Thus, the resulting groundwater level courses always reflected the shallowest continuous aquifer in the locality of interest, which comprised the saturated zone of both sludge beds, the quaternary aquifer at the inflow (sandy gravels), the near-surface aquifer of the shallow groundwater circulation connected in the east to a broad alluvial plain of the original stream bed (connecting to surface waters), and also in the north-east part of the second sludge bed a partial show of tertiary water recharge (coal seam outbursts). Thus, the determined groundwater level represented the highest possible level of the continuous course.

Considerable deep groundwater circulation (mostly a crevice aquifer in Cretaceous sediments and tertiary vulcanites and deposits) was found under the modelled course of the shallow groundwater level (pore character of the aquifer) and had virtually no bearing on the transport of contaminants solved by us; therefore, it was not included in the implemented simulations.

The modelled groundwater level course imitated to a large extent the terrain sloping and slope direction. Furthermore, it was obvious that the closer to the residual lake the calculated groundwater level was, the more the shallow groundwater levels gradually evened out, approaching the level corresponding to the free water surface of the sludge lagoon. Therefore, the simulated steady groundwater flow indicates communication between the groundwaters from both sludge beds.

In the case of Model 1, the groundwater quality was shown as constant, representing the current state. The comparison of calculated values of the monitored chemical indicators with average values documented by monitoring in the reference period from 2009 to 2016 showed very good agreement. The achieved values of individual potential contamination parameters served as input data for the further solution variant implemented in Model 2.

Model 2 solved the groundwater quality prediction for the following chemical indicators: dissolved inorganic salts (RAS), ammonium ions, sulphates and arsenic. As mentioned above, it was based on the current state calculation for groundwater quality (Model 1) and simultaneously on Model 3, which focused on the change in outflow conditions, or rather the state of the groundwater levels from sluicing discontinuation till the creation of the final secondary energy by-product body, i.e., till 2025.

The simulation of groundwater quality development from the beginning of secondary energy by-product depositing is quite a complicated operation; therefore, it is partially burdened with error. From the initial phase of the numerical calculation, i.e., from the time when the first sludge bed operation started in 1967, a significant leap in groundwater quality can be observed from this "zero" point up to the current state. It follows that the gradual deterioration of contamination up to the current state (for approx. 50 years) has a long-term tendency and therefore, no rapid or considerable improvement can be expected in the upcoming years (i.e., from the time when sluicing / secondary energy by-product depositing is discontinued). The calculated values of the monitored parameters had a relatively good agreement with the measured values of these chemical indicators in the long term. Inaccuracies in simulations compared with the measured data got worse towards the borders of both sludge beds.

The mathematical calculation of the current state was followed by the calculation of groundwater quality prediction in time, i.e., its change from 12/2017 till 2025. It was obvious in all the monitored cases that the equilibrium of the hydrochemical environment did not hold steady at the time when secondary energy by-product depositing was discontinued. The contaminant cloud moved very slowly in time and the contaminants will most probably never be washed completely out of both sludge beds, because of the lack of a sufficient gradient and (ground) water recharge, as shown in the results of Model 4.

It should be noted that according to the calculations, the water regime will stabilise in approximately 2042 , which means 25 years after sluicing to the sludge bed is discontinued and 17 years after depositing of the stabilised mixture is discontinued (before reclamation).

In the case of all chemical indicators, the modelling showed that all their monitored values decreased in time after sluicing was discontinued. At the end of the solved period (from approximately 2022), a partial decrease in the monitored concentration parameters started to show also in wells located at the outflow from both sludge beds. A detectable decrease in values of the monitored concentration parameters inside the sludge bed bodies would require a longer time period.

For most indicators, the concentration values documented by the model for the final year 2025 were lower in all monitored wells than the maximum value found in the selected monitoring period of $2009-2016$. In half of the cases, the calculated values (for 2025) were lower than the average values in the above-mentioned reference period. 


\section{CONClusions}

We can conclude that the indicated development of groundwater quality showed a clear tendency. That is, after discontinuation of sluicing, the contaminant cloud was gradually washed out, diluted and moving outside the sludge bed. However, the development depended not only on depositing of the secondary energy by-product but primarily on the hydraulic transport operation. If, theoretically, the sludge bed was supplied only with clear water through the sluice pipeline, the contaminant cloud could be gradually pushed out of the sludge bed and almost eliminated in the end. It means the cloud movement also implies a certain dilution, i.e., a decrease in contaminant concentrations. It is also quite obvious that the washing-out of contaminants will be considerably affected by the volume of inflows from the gravel aquifer. To the contrary, if substantial recharge of the sluicing water is missing, both concentration decrease and contaminant cloud movement will slow down; according to numerical modelling there will be an increase in concentrations of the monitored parameters inside both sludge bed bodies.

Another issue connected with the potential adverse effect of finishing the sludge lagoon (a change in hydroregime and thus the stability of the area of interest) is maintaining the drainage system function until the water regime completely stabilises. The performed model calculations have implied that it is necessary to operate the drainage system at least until the groundwater flow stabilises, i.e., for approx. 15 years after depositing of the secondary energy by-product in the area of interest is discontinued.

None of the model cases required any adjustment of limit values in the number of internal and mainly external iterations in order to increase the tolerance for achieving convergence above the size of one-tenth of a computing cell. A very good agreement with initial times was achieved for the values obtained from the model and the field measurement, thanks to calibration and backward verification.

The main uncertainty in the results obtained was the issue of course continuity of the groundwater level. The numerical calculation did not allow modelling of isolated saturated places; it is intrinsically made to solve a continuous course of the groundwater level. This results in a certain simplification and distortion; in reality, there will be separated, preferential groundwater flows in some isolated localities which will also allow the transport of contaminants.

\section{REFERENCES}

[1] P. Černoch, J. Koštál. Studie vlivu změn hydrorežimu na stabilitu odkališt. In Proceedings of conference Geotechnics 2016. Orgware, 2016.

[2] P. Černoch, J. Koštál. Implementation of geotechnical risks during realization of a slag dam based on the sediments in a former sludge lagoon. In Proceedings of $16^{\text {th }}$ conference ECSMGE. ICE Publishing, 2015.

[3] P. Černoch, J. Koštál. Řešení ukládání vedlejších energeticých produktů do prostoru odkaliště. In Proceedings of $14^{\text {th }}$ Congress of Hydrogeology and $2^{\text {nd }}$ Congress of Engineering Geology. ČAH, 2014.

[4] P. Černoch, J. Koštál. Stanovení zatěsnění úložného prostoru vedlejších energetických produktu na základě experimentu in situ. Geotechnika journal 2, 2016.

[5] P. Černoch, J. Koštál. Uplatnění hydrogeologického modelování při ukládání VEP. In Proceedings of $3^{\text {rd }}$ International Conference Popílky ve stavebnictví and $2^{\text {rth }}$ International Symposium Sanace 2017. VUT Brno, 2017. 